\title{
Sediment predictions in Wadi Al-Naft using soil water assessment tool
}

\author{
Imzahim Abdulkareem Alwan ${ }^{1 *}$, Ibtisam Karim ${ }^{1}$, and Mahmood Mohamed $^{2}$ \\ ${ }^{1}$ Building and Construction Department, University of Technology, Baghdad, Iraq \\ ${ }^{2}$ Ministry of Water Resources, Baghdad, Iraq
}

\begin{abstract}
Sediment production is the amount of sediment in the unit area that is transported through the basin by water transfer over a specified period of time. The main aim of present study is to predict sediment yield of Wadi, Al-Naft watershed with $8820 \mathrm{Km}^{2}$ area, that is located in the North-East of Diyala Governorate in Iraq, using Soil-Water Assessment Tool, (SWAT) and to predict the impact of land management and the input data including the land use, soil type, and soil texture maps which are obtained from Landsat- 8 satellite image. Digital Elevation Model,(DEM) with resolution $(14 \times 14)$ meter is used to delineate the watershed with the aid of model. Three Land-sat images were used to cover the study area which were mosaic processed and the study area masked- up from the mosaic, image. The area of study has been registries by Arc-GIS 10.2 and digitized the soil hydrologic group through assistant of Soil Plant Assistant Water Model, (SPAW) which was progressed by USDA, Agricultural, Research Service, using the data of soil textural and organic matter from Food and Agriculture Organization (FAO), the available water content, saturated hydraulic conductivity, and bulk density. The results of average, sediment depth and the maximum upland sediment for simulation period (2010-2020) were predicted to be $(1.7 \mathrm{~mm})$, and (12.57 $\mathrm{Mg} / \mathrm{ha}$ ), respectively.
\end{abstract}

\section{Introduction}

The Soil and Water Assessment Tool (SWAT) was developed by the US Department of Agriculture to predict the impact of land management, practices on water, sediments and agrochemicals yield [1]. It is necessary to minimize requirements data in order to get accurate watershed response. Model accuracy is important for implementing -effective practices of watershed management, [2]. The required watershed data such as: land use / land cover, soil characteristics, topography, or digital elevation model (DEM), require GIS to facilitate modeling of the model parameterization. Hydrological modeling system data should be collected such as soil characteristics, topography, land use / land cover. SWAT is an existing model and requires many data such as: weather variables, soil characteristics, terrain, land cover and land use occurring in the watershed area.

Many researchers have been using SWAT to predict the sediment yield. Radaideh, J, et al (2009) [3] evaluated the quality of rainwater collected and stored in the public water supplies by government agencies in the cisterns and storage tanks. Nayak1,T, (2012) [4] used the SCS-CN method to study the hydrological response in the Development of watersheds to identify potential changes in surface runoff in watersheds as a consequence of planned or unplanned land-use changes Mahasneh, L in (2013) [5]. The effects of water collection interventions on sediments, quality and runoff were studied. The study adopted the SWAT model to predict the effects of water harvesting interventions on biophysical and hydrological parameters.

\section{SWAT - sediment simulation}

SWAT is an extended code, watershed-scale simulation model with daily time- step operation and is planned to evaluate the effect of several administration water practices, agricultural chemical yields as well as sediment. It has physically, established effective computation and is accomplished of simulating a wide level spatial parts. Most parameters of the model for predicting sediment contain: climate, crop growth, hydrology, soil temperature, sediment, pesticides, nutrients and, land management [6].

The model was presented for continuous simulation, as reflected in single event models. Physical procedures related crop growth, flow water, sediment transport, nutrient distribution, etc. are modeled by (SWAT) directly using above mentioned input data. Model

Dr.Imzahim Abdulkareem Alwan: 40164@uotechnology.edu.iq 
advantages include: simulation of un-gauged watershed, prediction of effect of successive input data such as: changes in management practices, vegetation, water quality and climate. The model also generates weather data as follows: precipitation, relative humidity, solar radiation, wind speed, average temperature of the month and above data variables. It provides useful system to fill in daily missing data in the observed parameters [7]. SWAT watersheds are divided into several sub-watersheds, further subdivided into a single land use / land use known as hydrological response units, HRU. [8].

ArcSWAT divides a catchment into discrete units having the spatial variant of the main physical and hydrological characteristics and processes can be treated as being homogeneous. Landuse/Landcover and the soil maps within sub-basin limits used for generating single group and all groups will be considered as a similar physical property named as Hydrological Response Unit (HRU).

Water balance for each HRUs calculated at a daily time stage. ArcSWAT divided the river basin into subdivisions having like soil and land properties and that are found in the same sub-basin.

\section{Runoff modelling}

The model selected for the application to the Wadi Al-Naft watershed, is ArcSWAT ver. 2012. The model applies SCS Curve Number (CN) method for estimating direct run-off volume response from rain storms, [9]. This method simulates infiltration loss, although it may account interception surface storage losses through its initial abstraction characteristic [10]. Watersheds have a certain group of soil and fair pasture cover can be classified by various Curve Numbers. These Curves represent rainfall and runoff relationship, such that, [11]:

$$
F / S=Q / P
$$

$F:$ Actual retention (mm).

$S$ : Potential retention $(\mathrm{mm})$.

$Q$ : Actual runoff $(\mathrm{mm})$

$P$ : Total rainfall $(\mathrm{mm})$.

Initial abstraction,Ia, is all losses before runoff begins. It includes water retention in surface depression and intercepted by vegetation, infiltration, and evaporation as shown in Figure (1).

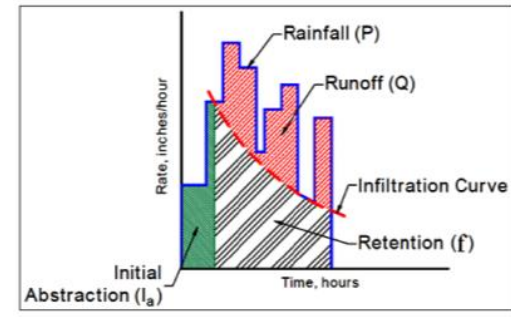

Fig. 1. SCS Curve Number (CN) Method, [10]. yields

Ia is subtracted from rainfall $\mathrm{P}$ in equation (1)

$$
(P-I a-Q) / S=Q /(P-I a)
$$

Solving for $Q$ yields

$$
Q=\frac{p-0.25 S}{p-I a+S}
$$

\section{Sediment component}

The model calculates sediment yield produced by rainfall and runoff and used the modified universal soil loss equations[12], which is given by equation $4,[13]$.

$$
\begin{gathered}
\text { sed }=11.8\left(\mathrm{Q}_{\text {surf }} * \mathrm{q}_{\text {peak }} * \operatorname{area}_{\text {hru }}\right)^{0.56} * \mathrm{~K}_{\mathrm{USLE}} * \mathrm{C}_{\mathrm{USLE}} * \mathrm{P}_{\mathrm{USLE}} * \\
\mathrm{LS}_{\mathrm{USLE}} * \mathrm{CFRG}
\end{gathered}
$$

sed: sediment yield (metric tons/day).

$Q_{\text {surf }}:$ surface runoff rate $(\mathrm{mm} / \mathrm{ha}$.).

$q_{\text {peak }}$ : peak runoff rate $\left(\mathrm{m}^{3} / \mathrm{s}\right)$.

area $_{h r u}$ : area of each HRU (ha.).

$K_{U S L E}:$ soil erodibility factor of USLE.

$C_{U S L E}$ : cover and management factor of USLE.

$P_{U S L E}:$ support practice factor of USLE.

$L S_{U S L E}$ : topographic factor of USLE and,

$C F R G$ : Factor of coarse fragment.

ArcSWAT uses either the variable storage routing or Muskingum River routing technique to route flow of water. The routing model that simulates the transport of sediments in the channel network includes two components of sedimentation and degradation.

The maximum amount of transferred sediments is a function of the peak velocity of the channel using the following equation, [14].

$$
\text { conc }_{\text {sed,ch,mx }}=c_{s p} * v_{c h, p k} \text { spexp }
$$

In which:

conc $_{\text {sed,ch,mx }}$ : Maximum transported sediment $(\mathrm{kg} / \mathrm{L})$. 
$c_{s p}: \quad$ Factor defined by the user.

$v_{c h, p k}:$ Peak velocity of the channel $(\mathrm{m} / \mathrm{s})$, and

spexp: Exponent varies between 1 and 2 and was set 1.5.

The maximum concentration of sediment calculated with formula five is compared with the concentration of sediment in the reach at the initial time step, conc $_{\text {sed,ch,i }}$.

- If conc $_{\text {sed,ch,i }}<$ conc $_{\text {sed,ch,mx }}$ deposition is the prevalent process in reach, and the remaining amount of sedimentation calculated by the formula (6).

- If conc $_{\text {sed,ch,i }}>$ conc $_{\text {sed,ch,mx }}$ degradation is the prevalent process in reach and the net amount of sediment is computed by the formula (7) $[14]$.

$$
\begin{aligned}
& \operatorname{sed}_{\text {dep }}=\left(\text { conc }_{\text {sed }, \text { ch }, i}-\operatorname{conc}_{\text {sed,ch }, m x}\right) * V_{c h} \\
& \text { Sed }_{\text {deg }}=\left(\text { conc }_{\text {sed,ch,mx }}-\operatorname{conc}_{\text {sed }, c h, i}\right) * V_{c h} * K_{C H} *
\end{aligned}
$$

sed $_{\text {dep }}:$ Ssedimentation quantity [metric tons].

conc $_{\text {sed }, \text { ch }, i}$ :Iinitial sediment concentration $(\mathrm{kg} / \mathrm{L})$.

conc $_{\text {sed,ch,mx }}$ : Ceiling concentration of sediment $(\mathrm{kg} / \mathrm{L})$. $V_{c h}:$ Water volume in the reach part $\left(\mathrm{m}^{3}\right)$.

Sed $d_{\text {deg }}$; Quantity of sediment entrained in the reach part (metric tons).

$K_{C H}$ : Parameter of channel erodibility $(\mathrm{cm} / \mathrm{hr} / \mathrm{pa})$, and

$C_{C H}$ : Parameter of the channel cover.

Ending quantity of the reach sediment is located via the formula (8), [14].

$$
\operatorname{sed}_{c h}=\operatorname{sed}_{c h, i}-\operatorname{sed}_{d e p}+\operatorname{sed}_{d e g}
$$

$\operatorname{sed}_{c h}$ : Quantity of reach suspended sediment (metric tons).

$\operatorname{sed}_{c h, i}$ : Reach initial quantity of the suspended sediment (metric tons).

The quantity sediment conveyed out of reach is computed as [11]:

$$
\operatorname{sed}_{\text {out }}=\operatorname{sed}_{c h} \frac{V_{o u t}}{V_{c h}}
$$

sed $_{\text {out }}$ : Quantity of sediment, conveyed out of reach (metric tons).

sed $_{c h}$ : Reach suspended sediment (metric tons).

$V_{\text {out }}$ : Outflow volume during the time step $\left(\mathrm{m}^{3}\right)$.

$V_{c h}$ : Water volume in the reach segment $\left(\mathrm{m}^{3}\right)$.

\section{Wadi Al-Naft Watershed}

Wadi Al-Naft watershed is located in the north east of Iraq republic. It lies in the north of Diyala Governorate

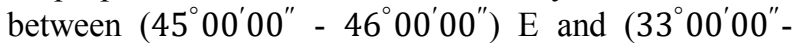
$\left.34^{\circ} 00^{\prime} 00^{\prime \prime}\right) \mathrm{N}$ along LandSat-8 track $(36,37)$ path and (168) row. The watershed area is about $8820 \mathrm{~km}^{2}$. Figure (2) illustrates the study area.

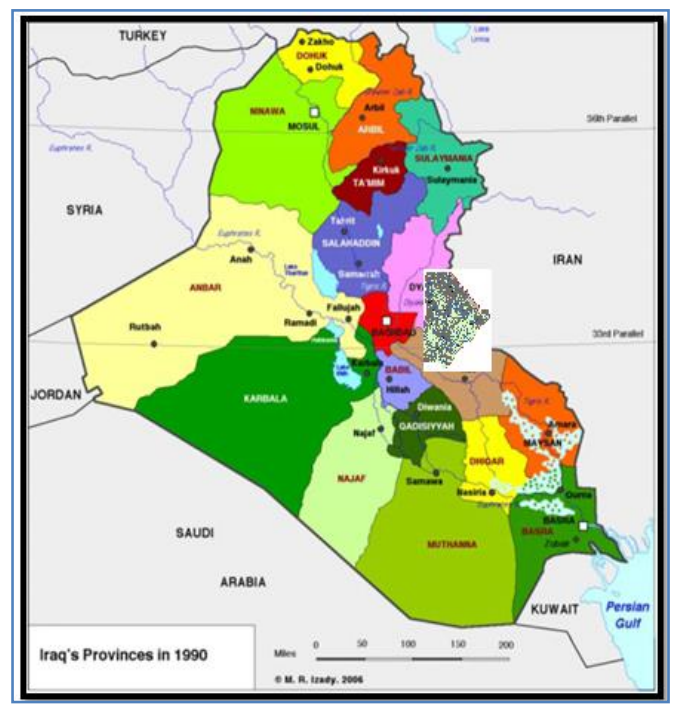

Fig. 2. Location of Wadi Al- Naft Region

\section{Data collection}

\subsection{Climate Data}

The Climate data rainfall, minimum and maximum temperature, solar, wind speed and relative humidity were obtained from Iraq Meteorological Organization and Seismology at Kanaqin station, for the period (2000 to 2014). The geographical location of Diyala Governorate is described as dry and hot in the summer months of June, July and August, with a temperature of 31.5 degrees Celsius. The climate of the region is usually windy through winter and the season ranges from December to February. The temperature in winter is about 7.6 degrees Celsius.

Relative humidity in summer to winter in succession was $25.5 \%$ to $65.6 \%$. While the evaporation is $53 \mathrm{~mm}$ in winter and $329.5 \mathrm{~mm}$ in the summer, where the wind speed in winter is $1.2 \mathrm{~m} / \mathrm{s}$ and in the summer $1.8 \mathrm{~m} / \mathrm{s}$. And finally the period of sunshine up to 5.1 and 10.6 hours in winter and summer, respectively.

\subsection{Digital Elevation Model}

Digital Elevation Model for Wadi Al-Naft region is loaded from the USGS website of Landsat8. Figure (3) shows DEM with resolution (14m). 


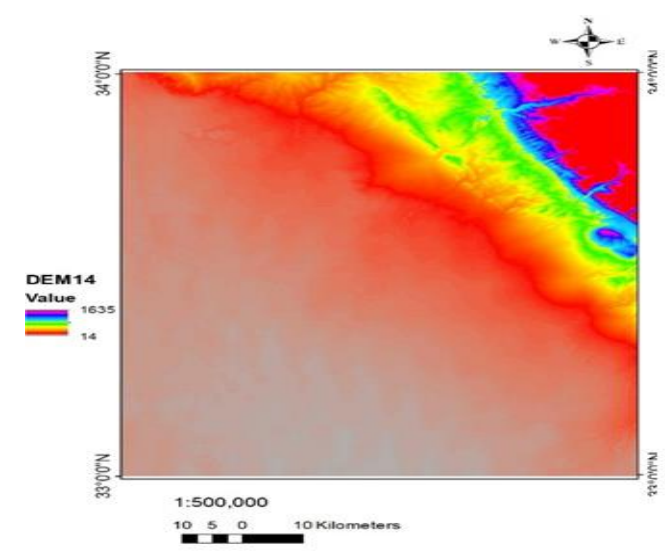

Fig. 3. DEM 14.0 mfor Wadi Al-NaftRegion.

\subsection{Landuse(LU), landcover(LC) and soil digital maps}

The satellite imagery, Land-sat 8 can be obtained from the USGS Website, which has three bands with $30.0 \mathrm{~m}$ spatial resolution which are used to produce the Landuse (LU) / Landcover (LC) map. Three Landsat images are utilized to cover the area of the valley.

However, the images were mosaic treated and the study area (Wadi Al-Naft) masked up from the mosaic image. Thematic mapping formulated Landuse (LU) / Landcover (LC) categories were classified into three types: agricultural land (34\%), forest -mixed (57\%) and water $(9 \%)$. Soil classes were achieved over supervised classification using technique of GIS software. According to exploratory soil map of Iraq 1960 and Land-use map at scale 1,000,000 Table (1).

The area of study has been registered by Arc-GIS 10.2 and has digitized the soil hydrologic group through assistance of Soil Plant Assistant Water Model, (SPAW), using the textural data and organic matter data from Food and Agriculture Organization (FAO), the available water content, saturated hydraulic conductivity and bulk density.

\section{Delineation digital elevation models}

Primarily when using the model of SWAT, it required illustrating the topographic characteristics such as: elevation above mean sea level, incline, flow network of creeks, and distance to nearest creek, and dividing the basin in sub-basin (sub-watershed).

Within SWAT the number of sub-basins to be included in the study, based on the smallest area of all sub-basins. Lesser account provided a large amount detail in the flat areas, greater account yields in subbasin that were also great in the mountainous areas.
The best sizes of sub-basin were gained by applying a threshold value of 3000 hectares in addition to manually adding more information in the mountainous area, resulting in the delineation in eighty three subcatchments through used DEM 14.0m., Figure (4).

Table 1. Soil Hydrologic Classification

\begin{tabular}{|c|c|c|}
\hline \multirow{2}{*}{ No } & Soil Hydrologic Classification \\
\cline { 2 - 3 } & Type of soil & $\begin{array}{c}\text { Percentag } \\
\text { e area }\end{array}$ \\
\hline 1 & Clay & 1.74 \\
\hline 2 & Clay loam & 9.25 \\
\hline 3 & Silty loam & 0.8 \\
\hline 4 & Loamy & 0.37 \\
\hline 5 & Loamy sand & 49.01 \\
\hline 6 & Sandy & 0.62 \\
\hline 7 & Sandy clay loam & 1.9 \\
\hline 8 & Sandy loam & 7.37 \\
\hline 9 & Silty & 14.73 \\
\hline 10 & Silty clay & 14.21 \\
\hline
\end{tabular}

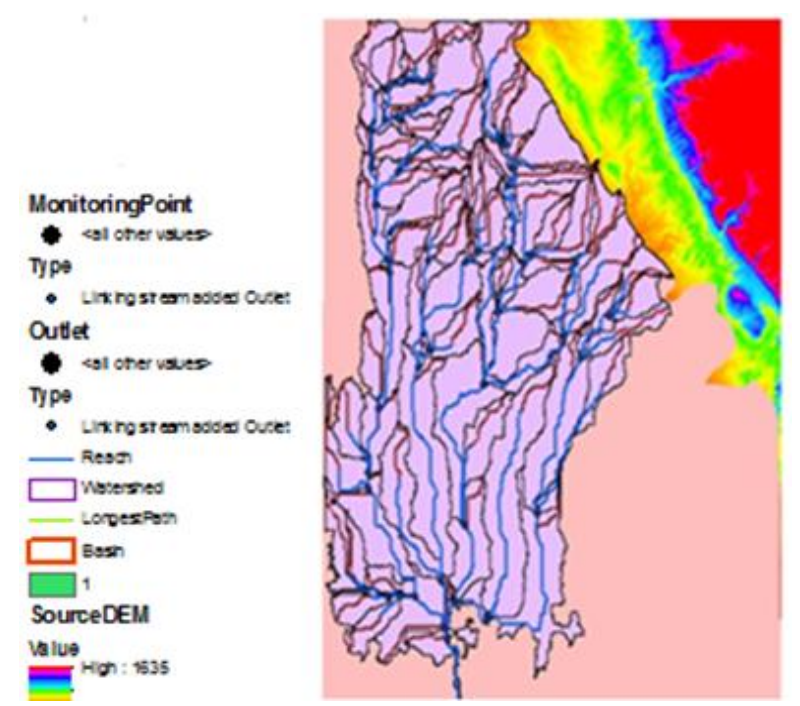

Fig. 4. Watershed Delineation and Stream Net.

\section{Hydrologic response unit analysis}

The application of (HRU) by subdividing the catchment area into numerous areas having same land use and soil incorporated assists the model to reflect changes in the hydrologic situations with various land covers, crops and soils to raise the accuracy of load predictions and provide physical description of the water balance.

Water flow is predicted separately for all Hydrology Response Unite and routed to get the whole overland for the watershed. Slope characterization is established upon the DEM defined in the watershed delineation. 
Datasets of the Landcover have been connected to the SWAT databases, soil texture and linked the result with SWAT datasets (Soil Hydrologic Groups). Figure (5), (6) and (7) illustrate slope, land cover and soil analysis from DEM (14m) resolution.

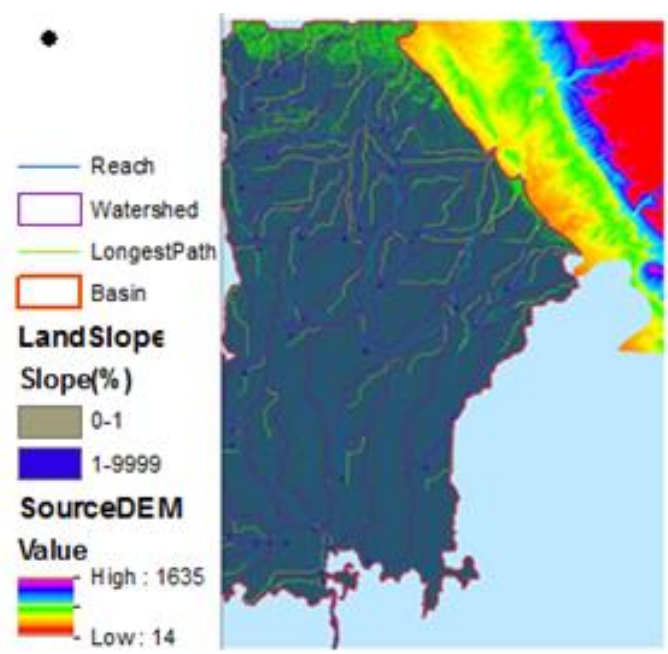

Fig. 5. Slopes Reclassified of Study Area.

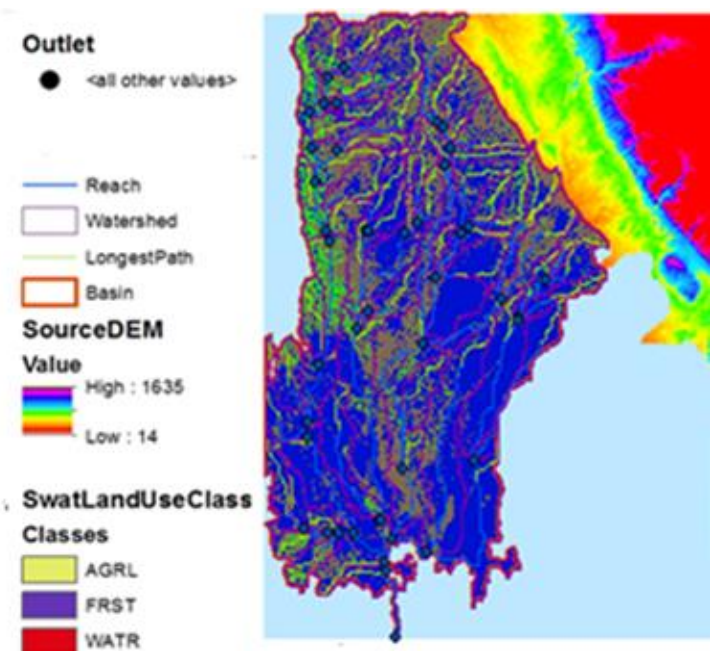

Fig. 6. Land cover Reclassified of Study Area.

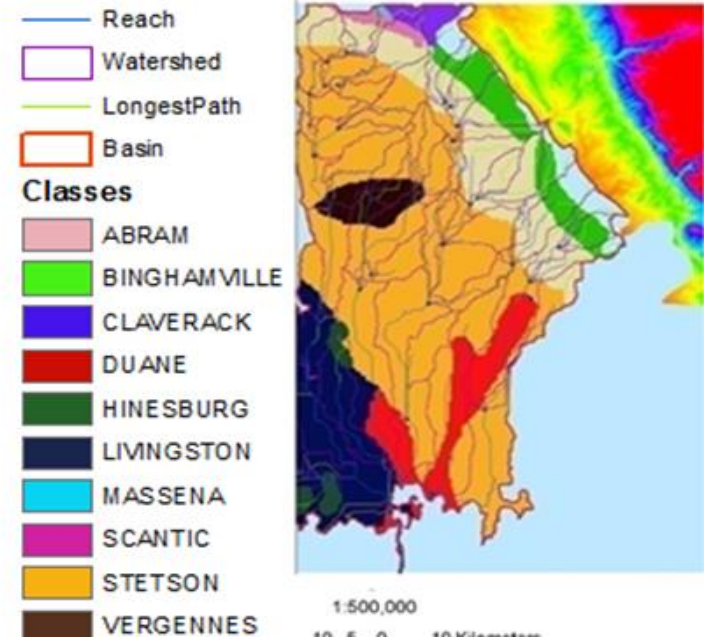

Fig. 7. Soil Reclassified of Study Area.

\section{Results and discussion}

To simulate the rate water flow status at the watershed region, net area after delineation step of the watershed DEM $4910.6 \mathrm{~km}^{2}$ was considered. Curve Number (CN) values ranged between (60 to 90). Soil of the study area is reclassified by SWAT model as in Fig. 7. The result of average sediment yield for the period of simulation (2010-2020) is found to be $(1.7 \mathrm{~mm})$ as illustrated in Table (2). Fig.8 and Fig.9 illustrate the sediment yield and the average maximum upland sediment yield with the value of $(12.57 \mathrm{Mg} / \mathrm{ha})$.

Table 2. Average Annual Sediment Yield.

\begin{tabular}{|c|c|c|}
\hline Year & $\begin{array}{c}\text { Surface Runoff } \\
\text { Depth(mm) }\end{array}$ & $\begin{array}{c}\text { Sediment } \\
\text { Yield } \\
\text { (mm) }\end{array}$ \\
\hline 2010 & 9.87 & 0.67 \\
\hline 2011 & 30.68 & 2.39 \\
\hline 2012 & 25.48 & 2.3 \\
\hline 2013 & 9.3 & 0.72 \\
\hline 2014 & 28.1 & 2.23 \\
\hline 2015 & 6.5 & 0.44 \\
\hline 2016 & 31.38 & 3.38 \\
\hline 2017 & 30.15 & 2.38 \\
\hline 2018 & 18.5 & 1.4 \\
\hline 2019 & 17.32 & 1.06 \\
\hline 2020 & 23.47 & 1.79 \\
\hline
\end{tabular}




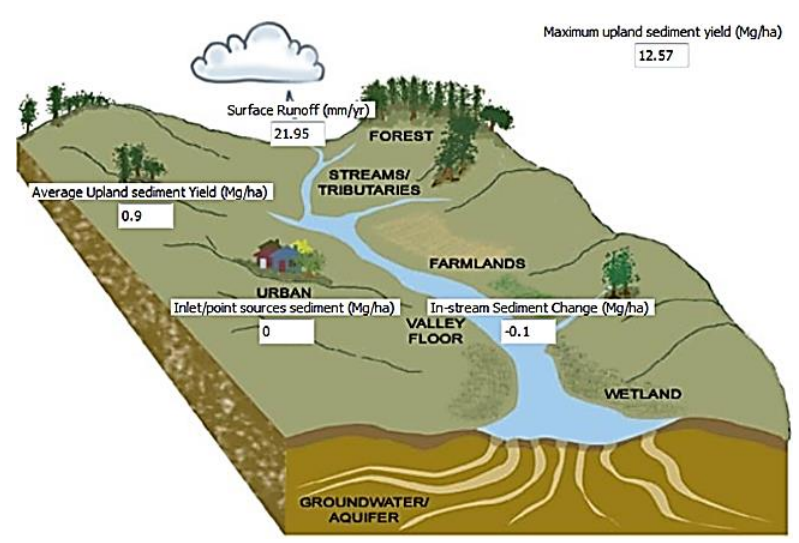

Fig. 8. Sediment Load.

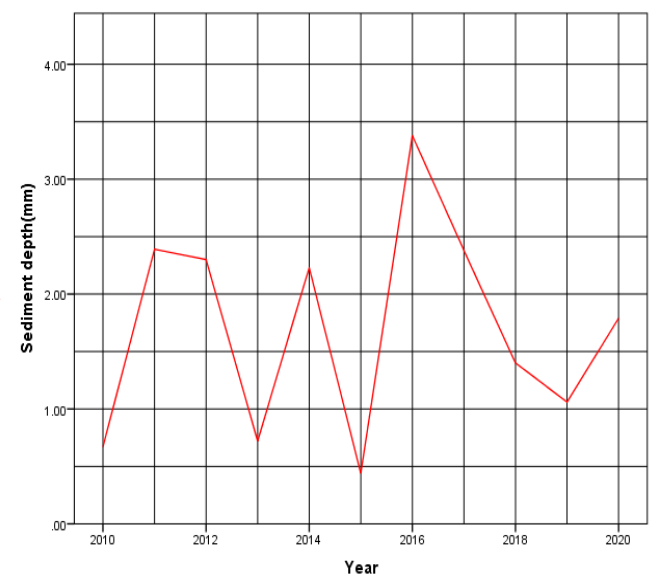

Fig. 9. Annual Sediment Depth.

\section{Conclusions}

- Stream flow is taking into account the influent via increase in the number of sub-watersheds because the overland flow is immediately associated with Curve Number, also the stream flow is not influent significantly via the size of the sub watersheds. There is a slight increase in stream flow because of an excess in conveyance gains (inter flow) and a contraction into conveyance losses as sub-watershed size drops.

- The produces of sediment predicted were immediately associated to sub-watershed size which showed a variation due to the sensitivity of overland incline, incline of the channel and drainage density. The variation factors reason for variation in sediment degradation and deposition, and, lastly, with sediment production.

- Primary parameters variance in sub-watershed delineations result in wide variance in the forecast sediment harvests. The results of predictions for sediments become stable for further improvements to the sub basin division, showing that there is a threshold level of division that cannot obtain more accuracy in predictions.

\section{References}

1. E.P. Querner1 and M. van Zanen. Van Hall Larenstein, University of Applied Sciences (2013).

2. Chow, V. T., Maidment, D.R., and Mays, L.W., New York, N.Y.: McGraw-Hill.(1988)

3. J.Radaideh ,K. Al-Zboon , A. Al-Harahsheh, and R. Al-Adamat, Jordan Journal of Earth and Environmental Sciences, Volume 2, Number 1 (2009).

4. T. Nayak, M. Verma, and H. Bindu, International journal of geometrics and geosciences Volume 3, Number 1,(2012).

5. L. Al-Mahassneh, SWAT conference, France.(2013).

6. S.Neitsch, J. G. Arnold, J.R. Kiniry, and J.R. Williams, Texas, USA: Texas Water Resources Institute.(2011).

7. Hawkins, H. Richard, Timothy, J. Ward, E. Donald Woodward, A. Joseph , and V. Mullen, American Society of Civil Engineers Publications.(2008).

8. Ponce, Victor, and H. Richard, Hawkins, Journal of Hydrologic Engineering; 11-19.(1996).

9. SCS, Soil Conservation Service, Technical Release 55.(1986).

10. Chow, Ven, Te, New York.(1964).

11. J.R.Williams, and R.W.Hann, Texas: Texas Water Resources.(1978).

12. C.T. Yang . The McGraw- Hill Companies. .New York.(1996).

13. J.R. Williams, Proceedings of the sediment-yield workshop, Oxford, MS, 1972, 244-252, (1975).

14. J.G. Arnold, and J.R. Williams, Agricultural Research Service Black land Research CentreTexas Argillite Research.(2012). 